\title{
SEBARAN RUANG TERBUKA HIJAU JAGAKARSA
}

\author{
Nia Rachmawati * \\ * Jurusan Arsitektur Univeristas Pancasila, Jl. Srengseng Sawah Jagakarsa Jakarta 12640
}

\begin{abstract}
Abstrak
Acceleration in urban development had impact to environment and urban spatial. The increase of physical development and urban infrastructure influence to decreasing quantity of green open space. The green open space needs as one of solution to bind up the relationship between human. The population increased as benchmark of green open spaces needed in the region. The purpose of this study is: (1) identify spread of green open spaces in Jagakarsa, (2) analize the needed of green open space The analysis method based on spread and land cover constrained by sub district and district garden in Jagakarsa. The spreading of district garden Jagakarsa had not spread which is need government policy to secure and increase spreading the green open space.
\end{abstract}

Keywords: green open space, spreading, need

\section{Pendahuluan}

Percepatan pembangunan di perkotaan berdampak pada perubahan lingkungan dan tata ruang kota. Peningkatan pembangunan fisik dan sarana prasana kota berdampak penurunan jumlah ruang terbuka hijau. Perubahan fungsi Ruang Terbuka Hijau menjadi sarana perdagangan atau perumahan merupakan salah satu bentuk kekurangan lahan akibat peningkatan jumlah penduduk. Jumlah penduduk meningkat berdasarkan deret ukur berbanding terbalik dengan jumlah penggunaan lahan meningkat sesuai dengan kebutuhan.

Pergeseran fungsi ruang terbuka hijau menjadi perumahan atau sarana prasarana perdagangan merupakan fenomena yang terjadi di perkotaan. Perubahan fungsi ruang terbuka hijau berdampak kepada perubahan sosial, budaya dan lingkungan masyarakat. Perubahan tingkah laku, kerenggangan hubungan antar individu sebagai pelaku komunitas menjadi salahsatu bentuk pergeseran sosial dan budaya di masyarakat. Kekurangan ruang untuk berkumpul berakibat kerenggangan antar individu sebagai pelaku dalam komunitas.

Ruang Terbuka Hijau diperlukan sebagai salahsatu solusi untuk mengikat kembali hubungan antar individu. Ruang Terbuka Hijau kota Ruang Terbuka Hijau (RTH) kota adalah bagian dari ruang-ruang terbuka (open spaces) suatu wilayah perkotaan yang diisi oleh tumbuhan, tanaman, dan vegetasi (endemik, introduksi) guna mendukung manfaat langsung dan/atau tidak langsung yang dihasilkan oleh RTH dalam kota tersebut yaitu keamanan, kenyamanan, kesejahteraan, dan keindahan wilayah perkotaan tersebut ( Direktorat
Penataan Ruang, 2008). RTH terdiri dari ruang terbuka alami merupakan kawasan hutan lindung dan kawasan ruang terbuka buatan. Ruang terbuka buatan atau binaan terdiri dari lapangan olahraga, pemakaman umum dan taman kota.

Ruang Terbuka Hijau dibangun bertujuan untuk (Carr, 1992) :

- Kesejahteraan Masyarakat, tingkat kesejahteraan masyarakat ditentukan ketersediaan ruang terbuka publik yang berfungsi menyediakan zona pergerakan manusia, pusat komunikasi dan tempat untuk berkumpul merasa bebas dan santai.

- Peningkatan Visual (Visual Enhancement), keberadaan ruang terbuka publik di wilayah akan meningkatkan kualitas visual dari wilayah tersebut menjadi lebih manusiawi, harmonis dan indah.

- Peningkatan Kualitas Lingkungan (Environmental Enhancement), kualitas lingkungan terbangun dari ruang terbuka hijau sebagai paru-paru kota. Vegetasi dan penghijauan berkontribusi terhadap kualitas udara di wilayah tersebut.

- Pengembangan Ekonomi (Economic Development), peningkatan kapasitas produksi berdaya guna bagi peningkatan ekonomi masyarakat. Peningkatan kualitas hidup masyarakat dengan memanfaatkan ruang terbuka produktif.

- Pemanfaatan RTH wilayah diharapkan berkontribusi bagi pembangunan wilayah dengan harapan peningkatan kesejahteraan masyarakat serta perbaikan kualitas hidup.

RTH merupakan salah satu sarana prasarana wilayah menjadi bagian terbentuknya suatu kota atau 
suatu wilayah. Kebutuhan RTH wilayah dianalisa berdasarkan jumlah penduduk wilayah tersebut. Parameter luasan RTH dihitung berdasarkan kapasitas pelayanannya terhadap sejumlah penduduk.

Kota Administrasi Jakarta Selatan salahsatu kota yang mengalami pembangunan pesat. Jakarta Selatan mempunyai hutan binaan Ragunan, hutan kampus UI dan Setu Babakan Jagakarsa yang berfungsi sebagai paru-paru kota bagi Kota DKI Jakarta. Wilayah Jakarta Selatan merupakan potensial pengembangan RTH. Kecamatan Jagakarsa yang berlokasi di Kota administrasi Jakarta Selatan menjadi salahsatu obyek pengamatan perkembangan RTH. Dinamika perubahan lahan RTH di kecamatan Jagakarsa menjadi pusat perhatian. Bergesernya pembangunan permukiman di Jakarta Selatan khususnya Jagakarsa menjadi titik tolak penelitian ini.

Kecamatan Jagakarsa berlokasi di selatan Kota Administrasi Jakarta dengan posisi 06'40'8" Lintang Selatan dan 106' 45'0,00" Bujur Timur dengan batas wilayah:

- Sebelah utara berbatasan Kelurahan Lenteng Agung

- Sebelah timur berbatasan dengan Kelurahan Lenteng Agung/Kali Ciliwung

- dan Kota Depok

- Sebelah barat berbatasan Kelurahan Cipedak / Kelurahan Ciganjur.

- Sebelah selatan berbatasan provinsi Jawa Barat.

Berdasarkan data BPS tahun 2015 , jumlah penduduk kecamatan Jagakarsa 297, 737 jiwa dengan kepadatan penduduk 12,474 jiwa/km2. Permasalahan dalam penelitian ini adalah: (1) apakah RTH di wilayah kecamatan Jagakarsa sesuai dengan jumlah penduduknya (2) apakah sebaran RTH dapat diakses penduduk dalam radius pelayanannya. Ruang lingkup penelitian ini adalah mengkaji dan menganalisis luasan RTH kecamatan Jagakarsa berdasarkan kebutuhan layanan masyarakat.

Tujuan dari penelitian ini adalah: (1) mengidentifikasi sebaran RTH di kecamatan Jagakarsa, (2) menganalisis kebutuhan RTH di kecamatan Jagakarsa.

\section{Metode Penelitian}

Data yang digunakan adalah data primer dan sekunder. Data primer adalah data penginderaan jauh, survey lapang dan sebaran RTH Kecamatan Jagakarsa. Data sekunder berupa data kependudukan dari Badan Pusat Statistik, Peta Administrasi Jakarta Selatan Tahun 2010 dan data dari instansi terkait. Tahapan Analisis dan pengolahan data yang dilakukan diuraikan dibawah ini.
Analisis Identifikasi Sebaran Ruang Terbuka Hijau Identifikasi sebaran RTH dilakukan melalui proses digitasi titik sebaran. Peta Penggunaan/Penutupan Lahan Kota Jakarta Selatan Selatan tahun 2012 diperoleh dari intrepretasi citra GeoEye dari Google Earth dengan cara on screen digitizing dengan mode online. Hasil digitasi kemudian diolah menggunakan sofware Global Mapper 11 dan ArcGIS 9.3 sehingga diperoleh peta Ruang Terbuka Hijau Kecamatan Jagakarsa.

\section{Analisis Kebutuhan Ruang Terbuka Hijau}

Kebutuhan Ruang Terbuka Hijau adalah perhitungan jumlah RTH yang diperlukan dalam suatu wilayah. Jumlah luasan RTH diperoleh dari hasil jumlah layanan terhadap jumlah penduduk. Kriteria kebutuhan RTH dianalisis menggunakan ratio layanan minimum. Perhitungan kebutuhan RTH dalam hirarki wilayah terkecil berdasarkan SNI-03-1733-2004 (Dirjen Penataan Ruang, 2004).

\section{Hasil Dan Pembahasan Identifikasi Sebaran Ruang Terbuka Hijau}

Sebaran Ruang Terbuka Hijau kecamatan Jagakarsa terdiri dari beberapa kategori yaitu: taman lingkungan/kota dikelola oleh SUDIN Pertamanan Jakarta Selatan, taman lingkungan perumahan dikelola oleh pengembang, taman kampus, Tempat Pemakaman Umum (TPU) wilayah kecamatan dan hutan kota Universitas Indonesia, lahan hijau di sekitar danau dan kebun campuran yang dikelola penduduk. Danau berlokasi di Setu Babakan, danau Kampus ISTN dan danau Universitas Indonesia. Kebun Campuran milik penduduk tersebar selatan dan barat dari kecamatan Jagakarsa. Taman lingkungan kampus berlokasi di timur dan selatan wilayah kecamatan Jagakarsa. Taman lingkungan pendidikan terdiri menjadi taman Sekolah dari tingkat dasar hingga menengah atas, dan taman kampus. Taman pendidikan tersebar merata di setiap wilayah kecamatan Jagakarsa.

Sebaran Ruang Terbuka Hijau Kecamatan Jagakarsa disajikan Gambar 1. Penggunaan lahan untuk perumahan tersebar merata di wilayah Kecamatan Jagakarsa. Lokasi perumahan padat terletak di Utara wilayah kecamatan Jagarsa yang berbatasan dengan kecamatan Pasar Minggu. Wilayah Utara Kecamatan Jagakarsa berkembang hunian baru. Luas wilayah Kecamatan Jagakarsa sebesar 24,87 km2, penggunaan lahan terbesar untuk permukiman dengan kepadatan penduduk 12,474 jiwa per km2 (BPS, 2010). 


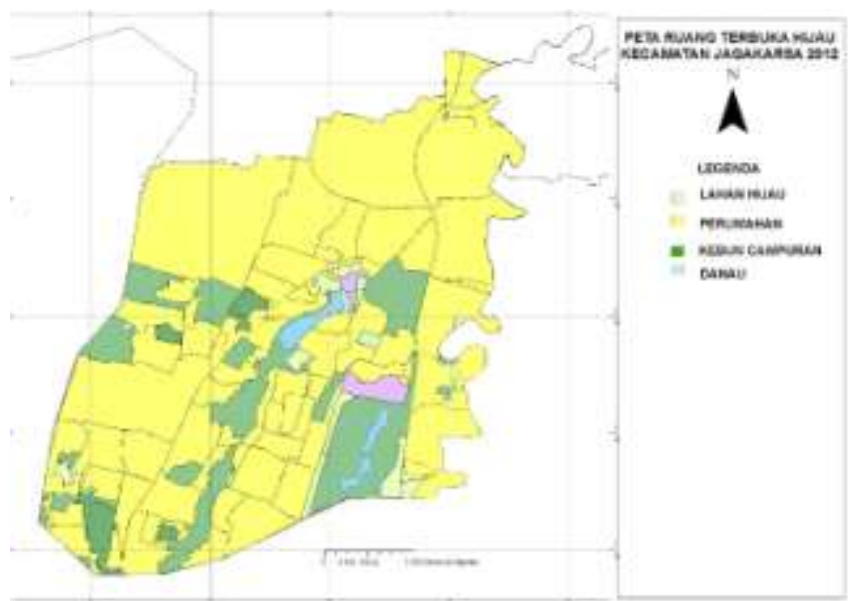

Gambar 1 Peta Ruang Terbuka Hijau Kecamatan Jagakarsa

Ratio diatas menggambarkan kecamatan Jagakarsa mempunyai tingkat kepadatan tinggi. Setiap $\mathrm{km} 2$ lahan dihuni oleh 12,474 jiwa, komposisi setiap km2 lahan kecamatan Jagakarsa dihuni sekitar 12,500 jiwa. Kepadatan tinggi memerlukan ruang gerak luas. Wilayah kecamatan Jagakarsa mengalami kekurangan ruang gerak karena penggunaan lahan didominasi oleh permukiman disajikan dengan warna kuning. Jumlah permukiman padat mengurangi jumlah RTH di kecamatan Jagakarsa. Wilayah Utara adalah wilayah terpadat, Barat dan Timur cukup padat, di Selatan terlihat beberapa lokasi RTH yang terdiri dari RTH sarana pendidikan, TPU dan RTH danau. Setu Babakan dan danau Universitas Indonesia disajikan dalam warna biru. Setu Babakan merupakan danau limpahan aliran sungai Ciliwung (Wikipedia, 2013). Setu Babakan merupakan kawasan Cagar Budaya Betawi termasuk dalam kawasan pariwisata di Jakarta Selatan

Tabel 1 Luasan Wilayah RTH Jagakarsa

\begin{tabular}{l|r}
\hline \multicolumn{1}{c|}{ Keterangan } & \multicolumn{1}{c}{ Luas $\left(\mathbf{M}^{\mathbf{2}}\right)$} \\
\hline Danau & $16,073.3$ \\
Danau UI & $48,013.3$ \\
Kebun Campuran & $1,601,951.8$ \\
Lahan Hijau UI & $687,954.6$ \\
Lahan Hijau & $638,277.4$ \\
Danau ISTN & $10,644.0$ \\
Danau Setu Babakan & $117,212.0$ \\
Ruang Terbuka & $79,694.9$ \\
Sarana Pendidikan dan Kesehatan & $32,020.1$ \\
Sarana Pendidikan (UI) & $131,444.0$ \\
\hline Jumlah Luas & $\mathbf{3 , 3 6 3 , 2 8 5 . 4}$
\end{tabular}

Sumber: Hasil Analisis, 2016

- Wilayah Setu Babakan merupakan wilayah konservasi berfungsi sebagai kontributor RTH di kecamatan Jagakarsa. Luasan wilayah Setu Babakan sebesar 117,212 m2 disajikan pada Tabel 1.

Ruang Terbuka Hijau wilayah kecamatan Jagakarsa terdiri dari : fasilitas olahraga di wilayah permukiman, sarana pendidikan, taman lingkungan, tempat pemakaman umum (TPU), lahan terbuka hijau serta kebun campuran. Luasan RTH kecamatan Jagakarsa terlihat pada Tabel 1. Jumlah luasan terbesar RTH kecamatan Jagakarsa sebesar $\quad 1,601,951.8 \mathrm{~m} 2$ dalam bentuk kebun campuran. Kebun campuran merupakan lahan milik warga yang dikelola swadaya terdiri dari kebun sayuran, buah-buahan dan kolam pemancingan. Lahan dan Hutan Universitas Indonesia dengan luasan 687,954 m2 kontributor kedua sebagai RTH kecamatan Jagakarsa. RTH Universitas Indonesia terdiri dari hutan binaan kawasan kampus dan lahan hijau di wilayah sekitar danau kampus Universitas Indonesia.

Lahan hijau kecamatan Jagakarsa seluas 638,277.4 m2 berlokasi taman-taman hijau, lahan kebun penduduk, hutan kota di Jalan Pembangunan Jagakarsa. Sarana pendidikan UI yang terdiri dari taman lingkungan kampus, kebun campuran lingkungan kampus, hutan dan ruang terbuka hijau lingkungan kampus seluas 131,444 m2. Ruang Terbuka Hijau (RTH) terkecil berlokasi di lingkungan Danau Institut Sains Teknologi Nasional (ISTN) seluas 10,644 m2. Terlihat dari uraian Tabel 1 sebaran RTH wilayah Jagakarsa tidak merata. Wilayah selatan Jagakarsa mempunyai luasasn lebih banyak RTH dibanding wilayah lainnya yang didominasi permukiman.

\section{Kebutuhan Terbuka Hijau}

Standar pelayanan sarana ruang terbuka hijau dihitung berdasarkan per jumlah penduduk berdasarkan SNI-03-1733-2004. Berdasarkan jenjang terendah di lingkungan sesuai dengan standar pelayanan.

a) taman untuk unit RT per 250 penduduk, sekurangkurangnya diperlukan $250 \mathrm{~m} 2$ atau dengan standar $1 \mathrm{~m} 2 /$ penduduk.

b) taman untuk unit RW per 2.500 penduduk, dibutuhkan minimal $1.250 \mathrm{~m} 2$ atau dengan standar $0,5 \mathrm{~m} 2 /$ penduduk yang lokasinya dapat disatukan dengan pusat kegiatan RW lainnya, seperti balai pertemuan, pos hansip dan sebagainya.

c) taman dan lapangan olah raga untuk unit Kelurahan per 30.000 penduduk, diperlukan lahan seluas $9.000 \mathrm{~m} 2$ atau dengan standar 0,3 $\mathrm{m} 2 /$ penduduk.

d) taman dan lapangan olah raga untuk unit Kecamatan $\square 120.000$ penduduk, diperlukan lahan seluas $24.000 \mathrm{~m} 2(2,4$ hektar) atau dengan standar $0,2 \mathrm{~m} 2 /$ penduduk.

e) kebutuhan jalur hijau seluas $15 \mathrm{~m} 2$ / penduduk yang lokasinya menyebar; 
f) Besaran lahan kuburan/pemakaman umum tergantung dari sistem penyempurnaan yang dianut sesuai agama dan kepercayaan masing-masing. Acuan perhitungan luasan berdasarkan angka kematian setempat dan/atau sistem penyempurnaan.

Kebutuhan ruang terbuka hijau kecamatan Jagakarsa dihitung berdasarkan perbandingan luas ruang terbuka hijau dengan jumlah penduduk. Perhitungan kebutuhan RTH pada penelitian ini dibatasi data ruang terbuka yang berfungsi sebagai taman dan lapangan olahraga. Jumlah penduduk kecamatan Jagakarsa 297.737 jiwa (BPS, 2015). Perhitungan kebutuhan ruang terbuka hijau disajikan dalam tabel 2.

Tabel 2 Kebutuhan Ruang Terbuka Hijau
Kecamatan Jagakarsa
\begin{tabular}{|l|l|c|c|}
\hline No. & Jenis Sarana & $\begin{array}{c}\text { Jumlah } \\
\text { Penduduk } \\
\text { (jiwa) }\end{array}$ & $\begin{array}{c}\text { Kebutuhan } \\
\left(\mathbf{m}^{2}\right)\end{array}$ \\
\hline 1. & $\begin{array}{l}\text { Taman dan } \\
\text { Lapangan } \\
\text { Olahraga }\end{array}$ & 297.737 & $59.547,4$ \\
\hline 2. & Jalur Hijau & 297.737 & $19.849,1$ \\
\hline \multicolumn{3}{|c|}{ Jumlah } & $79.396,5$ \\
\hline
\end{tabular}

Sumber: Hasil Analisis, 2016

Kebutuhan ruang hijau berupa taman dan lapangan olahraga 59,547 m2 disajikan dalam Tabel 2. Jumlah tersebut memperlihatkan kebutuhan luasan minimal taman dan lapangan olahraga di kecamatan Jagakarsa. Angka 59.547,4 m2 menggambarkan kebutuhan taman dan sarana olahraga untuk 297.737 jiwa. Kebutuhan jalur hijau kecamatan Jagakarsa sebesar 19,849 m2 dengan jumlah penduduk yang sama. Luas ruang terbuka di jenjang kecamatan Jagakarsa sebesar $79,496.5 \mathrm{~m} 2$. Jumlah tersebut dibandingkan luas hasil Tabel 1, ruang terbuka 79,694 m2. Ruang terbuka di wilayah Jagakarsa layak dan tercukupi. Fasiltas taman, lapangan olahraga untuk jenjang kecamatan Jagakarsa tercukupi.

Lokasi taman dan lapangan olahraga di wilayah Jagakarsa dan sebarannya berdasarkan data Dinas pertamanan dan pemakaman DKI Jakarta Selatan. Sebaran taman terdiri dari taman lingkungan, taman interaktif dan jalur hijau. Taman wilayah Jagakarsa terdiri dari taman lingkungan dan taman interaktif. Taman lingkungan lokasinya mulai dari jenjang Rukun Warga (RW) sampai dengan kelurahan. Taman lingkunagn dan taman interaktif jenjang kelurahan di wilayah Jagakarsa disajikan dalam Tabel 3.

Tabel 3 Luas Taman wilayah Jagakarsa

\begin{tabular}{|l|l|l|}
\hline No. & Nama Taman & $\begin{array}{l}\text { Luas } \\
(\mathbf{m} 2)\end{array}$ \\
\hline
\end{tabular}

\begin{tabular}{|c|c|c|}
\hline \multirow[t]{2}{*}{1} & Taman Jihandak & \multirow[b]{2}{*}{882} \\
\hline & & \\
\hline 2 & Taman Pintu KA Srengseng Barat & \\
\hline & & 250 \\
\hline 3 & Taman Pulo Tanjung Barat & 62 \\
\hline 4 & Taman BPG depan & 600 \\
\hline 5 & Taman Bibit Kebun Ciganjur & 48,670 \\
\hline 6 & $\begin{array}{l}\text { Taman interaktif Kebagusan dalam } \\
\text { I }\end{array}$ & 16,212 \\
\hline 7 & Taman interaktif Jagakarsa & 924 \\
\hline 8 & Taman interaktif Jl. M. Kahfi & 6,305 \\
\hline 9 & Taman Pintu KA Srengseng Timur & 315 \\
\hline 10 & Taman Lenteng Agung Timur & 357 \\
\hline 11 & Taman Publisistik depan & 360 \\
\hline 12 & Taman Lenteng Agung & 2,552 \\
\hline 13 & Taman Nangka & 250 \\
\hline & Taman Purwa Kav. DKI I & 24,606 \\
\hline 14 & Taman Purwa & 755 \\
\hline 15 & Taman depan UI (pintu gerbang) & 12,604 \\
\hline 16 & Taman Pondok Cina & 3250 \\
\hline 17 & Taman Tabebuya & 9,262 \\
\hline 18 & Taman Buni & 6,305 \\
\hline 19 & Taman Casuarina & 40,207 \\
\hline 20 & Taman Dadap merah & 20,000 \\
\hline 21 & Taman Spathodea & 10,524 \\
\hline 22 & Jumlah & 205,252 \\
\hline
\end{tabular}

Sumber:Dinas pertamanan dan pemakaman DKI Jakarta, 2016

Taman lingkungan terdiri dari pepohonan, tanaman bunga dan area bermain anak. Taman interaktif, selain pepohonan, tanaman bunga dan rerumputan. Taman interaktif berfungsi menampung kegiatan social masyarakat sebagai bentuk interaksi lingkungan. Taman interaktif dilengkapi dengan lapangan olahraga, jogging track, taman bermain. Taman - taman wilayah di Jagakarsa terdiri dari :

a. Taman di jenjang kelurahan Lenteng Agung terdiri dari : taman Lenteng Agung Timur, taman Publisistik depan Kampus Publisistik (IISIP), taman Lenteng Agung, jumlah luasan taman di wilayah Lenteng Agung $3.269 \mathrm{~m} 2$

b. Taman di jenjang kelurahan Srengseng Sawah terdiri dari: taman Jihandak, taman Pintu KA

c. Srengseng Barat, taman Pintu KA Srengseng Timur, taman depan UI (pintu gerbang), taman Pondok Cina. Jumlah luasan taman di wilayah Srengseng Sawah $17.301 \mathrm{~m} 2$.

d. Taman di jenjang kelurahan Ciganjur terdiri dari: taman Bibit kebun Ciganjur, taman interaktif Jl.M 
Kahfi, taman Tabebuya, taman Buni. Jumlah luasan taman di wilayah Ciganjur $70.642 \mathrm{~m} 2$.

e. Taman di jenjang kelurahan Jagakarsa terdiri dari: taman interaktif Kebagusan dalam I, taman interaktif Jagakarsa,taman Casuarina, taman Dadap Merah, taman Spathodea. Jumlah luasan taman di wilayah Jagakarsa $87.867 \mathrm{~m} 2$.

f. Taman di jenjang kelurahan Cipedak terdiri dari taman Purwa di Kavling DKI, taman Purwa di Jalan Purwa. Jumlah luasan taman di wilayah Cipedak $25.361 \mathrm{~m} 2$.

g. Taman di jenjang kelurahan Tanjung Barat terdiri dari taman BPG di Jalan Nangka Tengah, taman Pulo Tanjung Barat, taman Nangka. Jumlah luasan taman di wilayah Tanung Barat $912 \mathrm{~m} 2$.

Berdasarkan data Dinas Pertamanan dan Pemakanan Jakarta, wilayah Jagakarsa mempunyai jumlah dan luasan taman tertinggi sebesar $87.867 \mathrm{~m} 2$. Wilayah Tanjung Barat mempunyai luasan taman terendah sebesar $912 \mathrm{~m} 2$. Lenteng Agung, Srengseng Sawah, Ciganjur, Jagakarsa, Cipedak dan Tanjung Barat berada dalam kecamatan Jagakarsa Jakarta Selatan.

Jumlah luasan sebaran taman di enam kelurahan wilayah Jagakarsa sebesar $205.252 \mathrm{~m} 2$. Jumlah tersebut memenuhi kebutuhan taman per jiwa penduduk. Tetapi lokasi penyebaran yang tidak merata, terlihat dalam Tabel 4 wilayah kelurahan Tanjung Barat memerlukan $12.690 \mathrm{~m} 2$ taman. Jumlah taman saat ini di Tanjung Barat $912 \mathrm{~m} 2$ sehingga diperlukan penambahan taman sebanyak $11.778 \mathrm{~m} 2$. Kelurahan Lenteng Agung memerlukan 17.113,5 m2, jumlah luasan taman saat ini $3.269 \mathrm{~m} 2$ diperlukan $13.844 \mathrm{~m} 2$ taman. Lenteng Agung dan Tanjung Barat menjadi wilayah yang kekurangan RTH. Wilayah kelurahan Jagakarsa mempunyai luasan taman terbesar $87.867 \mathrm{~m} 2$, wilayah ini mempunyai jumlah luasan taman terluas dan melebihi kebutuhan taman yang diperlukan.

Tabel 4 memperlihatkan sebaran taman di jenjang kelurahan tidak merata. Jagakarsa, Ciganjur dan Cipedak mempunyai luasan taman lebih banyak dibandingkan wilayah lainnya. Sebaran taman tidak merata disebabkan karena perubahan fungsi lahan dari lahan hijau menjadi permukiman. Wilayah yang mengalami kekurangan taman mempunyai jumlah penduduk cukup tinggi yaitu: Lenteng Agung dan Tanjung Barat sehingga memerlukan lahan untuk rumah tinggal. Perlu peningkatan alih fumgsi lahan dari permukiman menjadi jalur hijau atau taman

Tabel 4. Kebutuhan Taman Jenjang Kelurahan

\begin{tabular}{|l|c|c|r|}
\hline Kelurahan & $\begin{array}{c}\text { Penduduk } \\
\text { (jiwa) }\end{array}$ & $\begin{array}{c}\text { Luasan } \\
\text { Sebaran } \\
\mathbf{m} 2\end{array}$ & $\begin{array}{c}\text { Kebutuhan } \\
\text { Taman } \\
\mathbf{0 . 3 m} 2 / \text { jiwa/m2 }\end{array}$ \\
\hline $\begin{array}{l}\text { Lenteng } \\
\text { Agung }\end{array}$ & 57.045 & 3.269 & $17.113,5$ \\
\hline Srengseng & 61.351 & 17.301 & $18.405,3$ \\
\hline
\end{tabular}

\begin{tabular}{|l|r|r|r|}
\hline Sawah & & & \\
\hline Jagakarsa & 62.574 & 87.867 & $18.772,2$ \\
\hline Cipedak & 36.652 & 25.361 & $10.995,6$ \\
\hline Ciganjur & 37.815 & 70.642 & $11.344,5$ \\
\hline $\begin{array}{l}\text { Tanjung } \\
\text { Barat }\end{array}$ & 42.300 & 912 & $12.690,0$ \\
\hline & 297.737 & 205.252 & $89.321,0$ \\
\hline
\end{tabular}

Sumber: Hasil Analisis, 2016

\section{Kesimpulan}

a. Luasan ruang terbuka hijau wilayah kecamatan Jagakarsa sebesar $\quad 3,363,285.4 \mathrm{~m} 2$ terdiri dari danau buatan ( kampus dan binaan), kebun campuran yang dikelola masyarakat, lahan hijau, lahan hijau kampus, ruang terbuka hijau dan sarana prasarana kampus (lapangan olahraga, taman).

b. Sebaran ruang terbuka hijau jenjang kecamatan khususnya taman dan jalur hijau merata dan sesuai dengan jumlah penduduk. Ratio pelayanan ruang terbuka hijau jenjang kecamatan Jagakarsa tercukupi.

c. Sebaran ruang terbuka hijau jenjang kelurahan tidak merata, di dua wilayah mengalami kekurangan taman sebagai bagian ruang terbuka hijau. Sementara di wilayah lainnya memunyai jumlah luasan melebihi dari kebutuhan layanannya.

d. Perlu peran pemerintah daerah menjaga dan meningkatkan jumlah taman dan jalur hujau di setiap wilayah. Ratio pelayanan ruang terbuka hijau per penduduk tercukupi.

e. Peningkatan jumlah taman dan jalur hijau dilakukan dengan menahan laju pertumbuhan permukiman, meningkatkan luasan jalur hijau, taman, sarana olahraga dengan pengalihan fungsi lahan dari permukiman menjadi jalur hijau dan taman.

\section{Daftar Pustaka}

Direktorat Penataan Ruang. 2008. Peraturan Pemerintah Pedoman Pemanfaatan Ruang Terbuka Hijau. Direktorat Penataan Ruang Kementerian Pekerjaan Umum.

BPS. 2015. Jagakarsa dalam Angka. Badan Pusat Statistik.

Carr, Stephen. 1992. Public Space. Cambridge University Press.

Direktorat Penataan Ruang. 2004. Standar Nasional Indonesia 03-1733-2004 Tata Cara Perencanaan Lingkungan Perumahan di Perkotaan. Direktorat Penataan Ruang Kementerian Pekerjaan Umum.

Dinas Pertamanan Pemakaman Jakarta. 2016. Sebaran Taman di Jakarta. http://dinaspertamananpemakamanjakarta.go.id. Diunduh 20 Juli 2016.

Wikipedia. 2013. Setu Babakan. http://wikipedia.setubabakan diunduh 13 Juni 2016 